\title{
IV. Account of the climate, natural products, arts, and manufactures of the Kingdom of Ashantee and some of the territories adjacent
}

\section{T. Edward Bowdich Esq.}

To cite this article: T. Edward Bowdich Esq. (1819) IV. Account of the climate, natural products, arts, and manufactures of the Kingdom of Ashantee and some of the territories adjacent , Philosophical Magazine Series 1, 54:255, 26-34, DOI: 10.1080/14786441908652177

To link to this article: http://dx.doi.org/10.1080/14786441908652177

曲 Published online: 29 Jul 2009.

Submit your article to this journal $\pi$

山 Article views: 2

View related articles 


\section{6}

Account of the Climate, Natural Products, Arts and

tistied almost every one of the truth of this conclusion : yet there is one point connected with it which does not appear to be so well understood; and which is, - that the same carriage will always do least injury to the roads when it moves with a considerable degree of velocity. For it has been shown that the depth of the impression is inversely as the square of the velocity (Prop. E). Consequently, the velocities being represented by the numbers $\quad \ldots \quad \ldots \quad 1,2,3,4,5,6, \& c$; $\left.\begin{array}{l}\text { the corresponding de- } \\ \text { pression will be }\end{array}\right\} 1, \frac{1}{4}, \frac{1}{9}, \frac{1}{10}, \frac{1}{25}, \frac{1}{86}$, \&.c. But the injury done to the road must be as the depth to which the wheel sinks into it; therefore the advantage gained in this respect by increasing the velocity is evident.

VIII. If the road were perfectly level, and of an uniform material; the resistance at the circumference of the wheel would be inversely as the cube root of its breadth, while the resistance at the axis would not be altered. That is, respresenting the breadths by $\quad . . \quad . \quad 1,2,3,4,5,6,7,8, \& c$. ;

the correspond- )

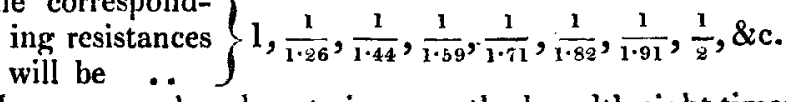

Hence, on such a plane to increase the breadth eight times would reduce the friction one-half. But this will not apply to common wheel-carriages, because the roads are not uniform; and it does not appear that any advantage can be gained by increasing the breadth of the wheel beyond a certain quantity, which depends on the size of the stones employed for making the road.

Such are the conclusions, to which a theoretical view of the subject has led. It is easy to extend the same reasoning to inclined roads, and to cases where the line of traction is not parallel to the road; - the resulting equations of course become more complicated, but they are not less important.

July l, 1819.

Thomas Tredgold.

IV. Account of the Climate, Natural Products, Arts, and Manufactures of the Kingdom of Ashantee and some of the Territories adjacent. By T. EdWaro Bowdich, Esq.*

\section{Climate.}

D Uring the first two months of our residence (May and June) it rained about one-third of the time; throughout July and August it rained nearly half, and abrupt totnadoes were frequent in the evening just after sunset, ushered in by a strong wind from the south-west. The heaviest rains were from the latter end of September to the beginning of November; they fell even in more

* Abstracted from Aocount of Mission from Cape Coast Castle to Ashantee in 1817 . impetuous 
impetuous torrents than are witnessed on the coast. The infiuence of the Harmattan was described as very powerful. Generally speaking, from the elevation of Ashantee (unfortunately we had no barometer), it was much cooler in Coomassie than at Cape Coast; indeed, from four to six in the morning there was a severity of cold unknown on the coast.

\section{Natural Products.}

The markets of Coomassie (the capital of Ashantee) were held daily from about eight o'clock in the morning until sunset. Amongst the articles for sale were beef (to us about eight-pence per pound), and mutton cut in small pieces for soup; wild hog, deer, monkey's flesh; fowls, and pelts of skins ; yams, plantains, corn, sugar-cane, rice, encruma (a mucilaginous vegetable richer than asparagus, which it resembles), peppers, vegetable butter, oranges, papaws, pine-apples (not equal to those on the coast), bananas; large snails smoke-dried and stuck in rows on small sticks in the form of herring hone; eggs for fetish, pittò, rum, palm-wine, \&c. \&c.

A fruit called boosie* is in great request. It is constantly chewed by the Ashantees on a journey; it is said to prevent hunger, and strengthen the stomach and bowels; has a slight bitter aromatic astringent taste, and causes an increase of the saliva while chewed. The boosie must be the gooroo-nut which $\mathrm{Mr}$. Lucas describes as one of the articles of trade between Fezzan, Kassina, Bornoo, and the states south of the Niger. He writes: "Gooroo-nuts which are brought from the Negro states on the south of the Niger, and which are principally valued for the pleasant bitter that they conmunicate to any liquor in which they are infused :"-And again; "A species of nut which is much valued in the kingdoms to the north of the Niger, and which is called gooroo." It grows on a large and broad-leafed tree that bears a pod of about eighteen inches in length, in which are inclosed a number of nuts that varies from seven to nine. Their colour is a yellowish green; their size is that of a chesnut, which they also resemble in being covered by a husk of a similar thickness; and their taste, which is described as a pleasant bitter, is so grateful to those who are accustomed to its use, and so important as a corrective to the unpalatable or unwholesome waters of Fezzan and of the other kingdoms that border on the vast Zahara, as to be deemed of importance to the happiness of life. They are purchased at the rate of $12 s$. for 100 pods.

Sal-ammonia is found abundantly in Dagwumba. In the Ashantee market, a lump the size of a duck's egg was sold for $2 s$.; they grind it to mix with their snuff (of which they rake large

* Sterculia acuminata, Palis, de Beauvais, Flore d'Ouware, i. p.41. tab.24. 
quantities), as it gives it a pungency agreeahle to them. They also dissolve it in the water they give to their cattle, and sometimes drink it themselves for pains in the bowels. The Tamool practitioners in the East Indies suppose it to be a useful remedy in certain female obstructions and morbid uterine enlargements.

Mr. Lucas writes : "No commercial yalue appears to be annexed to the fleeces whicht the numerous flocks of the Negro kingdons afford; for the cotton manufacture which the Shereef says is established among the tribes to the south of the Niger, seems to be the only species of weaving that is known among them." In Dagwumba, however, they manufacture a coarse kind of blanket from sheep's wool.

There is a white grease which has long been called Ashantee grease by the natives on the coast, who supposed it to be produced in that country. They use it daily to anoint their skins, which otherwise become coarse and unhealthy. The Ashantees purchase it from the interior, and make a great profit by it ; it is a vegetable butter decocted from a tree called timkeeea; it is doubtless the shea butter of Mr. Park.

The Ashantees procure most of their ivory from Kong, where they give eight ackies (or 40 s.) in barter for a very large tooth.

The cattle we saw in Ashantee were as large as the English, unlike those on the coast, which resemble the Jersey. The sheep are hairy in Ashantee, but woolly in Dagwumba, an open country where they manufacture a close blanket. The borses in Dagwumba are generally small; some were described to be fifteen hands high, but these were never parted with; and the Ashantees did not desire them, for I never saw but one who rode fearlessly. The horses I saw were like half-bred galloways; their legs lathy, with a wiry hair about the fetlock only requiring to be pulled. Their heads were large; dun and nouse colours were said to be common ; they were never shod, and their hoofs consequently in the eye of the European, though not in the native, disproportionate; they were fed on Guinea grass, occasionally mixed with salt, and sal-ammonia was frequently dissolved in the water. The saddles were Moorish, of red leather and cumbersome; the bridles of twisted black leather thongs, and brass links with a whip at the end; the bit severe, with a large ring hanging from the middle and' slipped over the under jaw instead of a curb chain: the stirrups were like large blow pans and hung very short. Some of the Moors rode on bullocks with a ring through the nose.

The extent and order of the Ashantee plantations surprised us; yet I do not think they were adequate to the population; in a military government they were not likely to be so. They are chiefly 
chiefly of corn, yams, ground-nuts, terraboys and encruma; the yams and ground-nuts are planted with much regularity in triangular beds, with small drains around each and carefully cleared from weeds. They use no implement but the hoe. They have two crops of corn a year, plant their yams at Christmas, and dig them early in September. The latter plantations had much the appearance of a hop-garden well fenced in and regularly planted in lines, with a broad walk around, and a hut at each wicker gate where a slave and his family resided to protect the plantation.

All the fruits mentioned as sold in the market grew in spontaneous abundance, as did the sugar-cane; the oranges were of a large size and exquisite flavour. I believe this fruit has hitherto been considered as indigenous to India only. We saw no cocoa-nut trees, nor was that fruit in the market. Mr. Park's route was through a very different country. In the marshy ground a large species of fern is very abundant; there are four varieties of it: in shady places that have been cultivated, various tribes of urtica; and the leontodon grows abundant to the north of Coomassie. The miraculous berry which gives acids the flavour of sweets, making limes taste like honev, is common*. The castor oil (Ricinus cornmunis) rises to a large tree; I have only seen it as a bush about three feet high on the coast; and the wild fig is abundant, though neither of them is used by the natives. The cotton plant is very plentiful, but little cultivated. The only use to which they apply the silk cotton is to the stuffing of cushions or pillows $\dagger$. Mr. Park observed the tobacco-plant which grows luxuriantly in Inta and Dagwumba, and is called poah. The visitors from those countries recognised it in a botanical work. They first dry the leaves in the sun; then, having rubbed them well between their hands, mix them with water into oval masses. The Ashantees, however, never use this tobacco when Portuguese tobacco can be got from the coast even at the most extravagant rate. They will sometimes give two ounces of gold for the roll of Portnguese tobacco. The Dutch governor-general has been known to receive eighty ounces of gold from the Ashantees for tobacco alone.

Lions are numerous on the northern frontiers of Inta; elephants are remarkably numerous in Kong, and they are also found in

* The curious fruit to which I have given the name of oxyglyeus, I find, was known to De Marchais, who describes it as a little red fruit, which being chewed gives a sweet taste to the most sour and bitter things.-Dalzel's Dahomey.

+ Cotton of the cotton tree (or silk cotton) Bombax pentandrium, Linn. This cotton is not used for thread, but is made into pillows and beds. It is also, from its catching fire so easily, commonly put into tinder-boxes and employed in the preparation of fire-works.-Ainslie's Materia Medica of Hindostan. 


\section{0}

Account of the Climate, Notural Products, Arts and

Ashantee, with wild hogs, hyænas, cows, sheep, goats, deer, antelopes; dogs approximating to the Danish; cats extremely sharpvisaged and long-necked; Gennet cats, pangolins, alligators. The rhinoceros is found in Boroom, and the hippopotamus in the Odirree river.

'I'he Ashantees say that an animal called sissah or sissiree will attack every other however superior in size. The Fantees, who had never seen it, had imbibed a tremendous idea of it from the stories in their own country. I doubt its being so formidable to all other animals, for the skin I saw was not more than three feet long and the legs short; it resembled that of a boar, but the natives said it was between a pig and a goat. It is extraordinary that the gnoo (antelope gnu) which is found behind the Cape of Good Hope is known in Inta by the same name. Where the beds were not an accumulation of cushions, the skin of the gnoo was nailed to a large wooden frame, raised on legs about a foot from the ground, and stretched as we would sacking. It was a revered custom that no virgin of either sex should sleep on this kind of bed. Another animal called otrum was described by the inhabitants of the eastern frontier as having one very long horn on one side of the head, and a short one on the other; it is much larger than the gnoo. We met with a spotted animal of the cat kind, very common, and allied to the leopard or panther ; but whether referable to either of those species, or to be considered as distinct, we could not determine, owing to the very vague and unsatisfactory character by which naturalists have atternpted to distinguish them,-the kind and numbers of the rows of spots; which we have observed in individuals of the same decided species to present almost an infinity of variation.

The vulture, which is venerated by the natives for the same reason that the Egyptians venerated the Vulturus percopterus, is the Vulturus monachus figured by Le Vaillant. Green pigeons are found, and crows with a white ring round their necks, probably the Corvus scapularis figured by Le Vaillant. There were several small birds of beautiful plumage which sung melodiously; two in particular, the one like a blackbird, and the other of the same colour as the English thrush, but larger. Also a variety of parrots beautifully spangled with different colours. M. Cuvier was misinformed when he wrote (Regne Animul, tome i. p. 108) "Macaque est le nom generique des singes à la côte de Guinée." The name is unknown there as well as in the interior. Dokoo is the generic name. The Simia Diana, which has the most beautiful skin of any monkey, is found in Ashantee as well as in Warsaw. All the natives agree that they do not know of any monkeys which dare to attack men but the akoneson, which they describe as small and always seen in troops. 
Snakes green and of all colours; scorpions, lizards, \&c. were found as on the coast, with a curious variety of beetles and the most beautiful butterflies. A few specimens preserved in spirits have been sent to the British Museum.

\section{Arts and Manufactures.}

The Ashantee loom is precisely on the same principle as the English; it is worked by strings held between the toes; the web is never more than four inches broad. A small loom complete is among the articles presented to the British Museum. They use a spindle and not a distaff for spinning, holding it in one hand, and twisting the thread (which has a weight at the end) with the finger and thumb of the other. The fineness, variety, brilliancy and size of their cloths is astonishing; a specimen which is in the British Museum will be admired for the two first qualities, and for having the same appearance on both sides. The richest red taffetas imported from India are unravelled, and wove into the cloths of their own manufacture. They are also sometimes in the custom of unravelling a few of the fancy silks (India), but these are generally bought for wear, though they prefer those from Fezzan for that purpose, because the colours are more showy. The richest silks I saw were worn by the Moors, who had bought them at Yahndi and Houssa. Reckoning nine inches to a span, there are eight spans in a fathom, which is the Ashantee measure; but the fathom of Inta and Dagwumba contains only six spans. Even if the Ashantee traders give only twenty shillings a fathom in barter of boosie, salt, rum, iron, \&c. it is considerably cheaper than ours (silks), considering that they get 100 per cent. on it at Coomassie. Mr.Lucas mentions " silk wrought and unwrought" among the articles exported from Fezzan to Kassina. Apokoo and several others related to me that Sai Cudjo bought a piece of silk at Yahndi so very fine, that although it could be compressed between two hands, it was nevertheless larger than any cloth I had seen the present king wear, and his appeared monstrous. Apokoo added that six slaves were paid for it, which would have produced $160 l$. at the water side.

A description of British cotton cloth (which goes here by the name of sarstracunda) is in considerable request. It is a highly glazed article, of bright red stripes with a bar of white, and is bought solely for the red stripe (as there is no red dye nearer than Marrowa), which the Ashantees weave into their own cloths, throwing away the white. The red dye of Marrowa, which is very good, is obtained from a tree called moosaratee.

The white cloths which are principally manufactured in Inta and Dagwumba they paint for mourning, with a mixture of blood 
and a red dye wood. The patterns are various and not inelegant, and painted with so much regularity with a fowl's feather that they have all the appearance of a coarse print at a distance. $I$ have seen a man paint as fast as I could write. There is a very fair specimen in the British Museum, the price of painting which was one ackie.

They have two dye woods, a red and a yellow, specimens of which I brought down. They make a green by mixing the latter with their blue dye, in which they excel; it is made from a plant called acassie, certainly not the indigo which grows plentifully on the coast. The acassie rises to the height of about two feet, and, according to the natives, bears a red flower; but the leaf is not small, fleshy or soft, nor is it pale or silvery coloured underneath; it is a thin acuminate leaf about five inches long and three broad, of a dark green. The shrub has opposite leaves, no stipules, and has a certain degree of resemblance to Marsdenia suaveolens (the indigo of Sumatra); but as the leaves are toothed in the acassie, it probably does not belong even to the same natural order. I regret to add, that our best specimens of this plant perished in the disasters of our march, and no drawing was made of it, as it bore no flower in that season; it grows abundantly in the woods, and produces a fast and beautiful colour without requiring a mordant. They gather a quantity of the leaves, bruise them in a wooden mortar, and spread them out on a mat to dry: this mass is kept for use; a proportion of it is put into a pot of water, and remrins six days previous to immersing the thread, which is left in six days, drying it once every day in the sun; it is then a deep lasting blue colour. When a light blue is wished for, the thread is only allowed to remain in the pot three days.

They excel in pottery, as the pipes in the Museum will show; they are rested on the ground when smoked; the clay is very fine, polished (after baking) by friction, and the grooves of the patterns filled up with chalk. They have also a black pottery which admits of a high polish.

The people of Dagwumba surpass the Ashantees in goldsmiths' work, though the latter mayy be esteemed proficients in the art. The small articles for the Museum-a gold stool, sanko bell, jawbone and drum - are not such neat specimens as I could wish; the man.who made, them having too much costly work on hand for the king, to pay our trifles his wonted attention; unfortunately too he was committed to prison before they were quite finished; however, they will give an ilea. I weighed out nineteen ackies and a half of gold-dust for making these articles; one-third of an ackie was lost in melting, and five was the charge. of the goldsmith. Bees'-wax for making the model of the article wanted is spread out on a smooth block of wood by the side of a fire, on 
which stands a pot of water; a flat stick is dipped into this, with which the wax is made of a proper softness; it takes about a quarter of an hour to make enough for a ring. When the model is finished, it is inclosed in a composition of wet clay and charcoal (which being closely pressed around it forms a mould), dried in the sun, and having a small cup of the same materials attached to it, (to contain the gold for fusion,) communicating with the model by a small perforation. When the whole model in $\mathrm{fi}$ nished, and the gold carefully inclosed in the cup, it is put in a charcoal fire with the cup undermost. When the gold is supposed to be fused, the cup is turned uppermost, that it may run into the place of the melted wax ; when cool the clay is broken, and if the article is not perfect it goes through the whole process again. To give the gold its proper colour, they put a layer of finely-ground red ochre (which they call juchuma) all over it, and immerge it in boiling water mixed with the same substance and a little salt; after it has boiled half an hour, it is taken out and thoroughly cleansed from any clay that may adhere to it. Their bellows are imitations of ours; but the sheep skin they use being tied to the wood with leather thongs, the wind escapes throigh the crevices; therefore when much gold is on the fire they are obliged to use two or three pair at the same time. Their anvils are generally a large stone, or a piece of iron placed on the ground. 'Their stoves are built of sursh (about three or four feet high) in a circular form, and are open about one-fifth of the circumference; a hole is made through the closed part, level with the ground, for the nozzle of the bellows. Their weights are very neat brass casts of almost every animal, fruit, or vegetable, known in the country. The king's scales, blow-pan, boxes and weights, and even the tongs which hold the cinder to light his pipe, were neatly made of the purest gold that could be manufactured.

'Their blacksmiths' work is performed with the same sort of forge as the above ; but they have no idea of making iron from ore, as their interior neighbours do. Their swords are generally perforated in patterus like fish troweis ; frequently they make two blades springing parallel from one handle which evince very fine workmanship. The needles and castanets will only give some idea of their progress. The iron-stone is of a dark-red colour, spotted with gray and intermixed with what has all the appearance of lava ; they cut bullets out of it for the army when lead is scarce. I have brought some arrows of native iron. They have no idea of making a lock like the people of Houssa and Marrowa.

They tan or dress leather in Ashantee, but they do this and dye it in a very superior manner in Houssa and Dagwumba ; - see the sandals and cushion in the British Museum, the former varied Vol. 54. No. 255. July 1819. and 
and apparently stitched: doubting that there could be such stitching, I undid a part, and discovered that they perforated the surface, and then stuck in the fine shreds of leather. The curious will observe that the patterns of the stool cushion are all produced by paring the surface. They make their soldiers' belts and pouches out of elephant or pig skin oriamented with red shells.

Of their carpenters' work the stool is a fair specimen, being carved out of a solid piece of a wood called zesso, white, soft, and bearing a high polish; it is first soaked in water. They sell such a stool for about three shillings; in Accra or Fantee it would fetch twenty. The umbrella is even more curious; the bird is cut almost equal to turning, and the whole is so supple that it may be turned inside out. This (only a child's umbrella) is a model of the large canopies I have described in the procession; I gave a piece of cloth value twenty shillings for it. The sanko or guitar is also neatly made, and the chasteness and Etruscan character of the carving is very surprising. The surface of the wood is first charred in the fire, and then carved deep enongh to disclose the original white in the stripes or lines of the patterns.

Numbers of workmen are employed in breaking, rounding and boring the snail shells, as big as a turkey's egg generally, and sometimes as large as a conch. They are first broken into numerous pieces; then chipped round, the size of a slecve-button, and afterwards bored with a bow and iron style fixed in a piece of wood. Lastly, they are strung and extended in rows on a log of wood, and rubbed with a soft and blueisti gray stone and water, until they become perfectly round.

Their pine-apple thread is very strong, and is made from the fineness of a hair to the thickness of whip-cord; it bleaches to a beautiful whiteness, and would answer for sewing any strong materials; but when muslin is stitched with it, it is liable to be cut from the harshness. The women frequently join their cloths and ornament their handkerchiefs with a zigzag pattern worked with unravelled silks of different colours. The fetish case is a specimen of their needle-work in the manner of chain stitch.

\section{On finding the Longilude by Lunar Observalions. By Mr. Henty Meikle.}

\section{To Mr. Tilloch.}

Sir, - The problem of finding the longitudendon, June 15, 1819. servations has long and justly been regarded as an interesting subject. To accomplish this desirable end, various methods of reducing the lunar distances have been proposed with different degrees of success. But while methods very different agree in 